Western North American Naturalist 69(3), ( 2009, pp. 371-381

\title{
THE EFFECTS OF VARIED DENSITIES ON THE GROWTH AND EMIGRATION OF ADULT CUTTHROAT TROUT AND BROOK TROUT IN FENCED STREAM ENCLOSURES
}

\author{
David J. Buys ${ }^{1,4}$, Robert H. Hilderbrand ${ }^{2}$, and Jeffrey L. Kershner ${ }^{3,5}$
}

\begin{abstract}
We evaluated the effects of various density treatments on adult fish growth and emigration rates between Bonneville cutthroat trout Oncorhynchus clarki utah and brook trout Salvelinus fontinalis in stream enclosures in Beaver Creek, Idaho. We used 3 density treatments (low, ambient, and high fish densities) to evaluate density-related effects and to ensure a response. Intraspecific ambient-density tests using cutthroat trout only were also performed. Results indicated an absence of cage effects in the stream enclosures and no differences in fish growth between ambient-density stream-enclosure fish and free-range fish. Brook trout outgrew and moved less than cutthroat trout in the stream enclosures, especially as density increased. In all 3 density treatments, brook trout gained more weight than cutthroat trout, with brook trout gaining weight in each density treatment and cutthroat trout losing weight at the highest density. At high densities, cutthroat trout attempted to emigrate more frequently than brook trout in sympatry and allopatry. We observed a negative correlation between growth and emigration for interspecific cutthroat trout, indicating a possible competitive response due to the presence of brook trout. We observed similar responses for weight and emigration in trials of allopatric cutthroat trout, indicating strong intraspecific effects as density increased. While cutthroat trout showed a response to experimental manipulation with brook trout at different densities, there has been long-term coexistence between these species in Beaver Creek. This system presents a unique opportunity to study the mechanisms that lead cutthroat trout to coexist with rather than be replaced by nonnative brook trout.
\end{abstract}

Key words: competition, cutthroat trout, brook trout, habitat.

The ability of introduced brook trout Salvelinus fontinalis to replace inland species of native cutthroat trout Oncorhynchus clarki is well documented (Eiserman 1958, Behnke and Zarn 1976, Oberholtzer 1990, Gresswell 1991, Behnke 1992, Remmick et al. 1993, Dunham et al. 2002) and may be the result of a number of mechanisms (Dunham et al. 2002). Competition has been hypothesized as one mechanism for replacement of native cutthroat trout by introduced brook trout (Griffith 1972, Novinger 2000, Peterson and Fausch 2003) and brown trout (McHugh and Budy 2005). Disease may play an important role where nonnative trout infected with pathogens interact with native cutthroat trout (Nehring and Thompson 2001). Predation may also play a role where larger nonnatives such as brown trout coexist with native species (Townsend and Crowl 1991).

Many workers believe that the decline in cutthroat trout populations is linked, in part, to the detrimental effects of interspecific competition with introduced brook trout (Griffith 1972, DeStaso and Rahel 1994, Thomas 1996, Novinger 2000, Buys 2002, Peterson et al. 2004). Brook trout emerge before cutthroat trout and are believed to have an immediate competitive edge over cutthroat trout of the same cohort, due to an initial size advantage (Griffith 1972). Brook trout are also known to aggressively occupy and defend energetically profitable stream positions from cutthroat trout and other trout species (Gibson et al. 1993, DeStaso and Rahel 1994, Thomas 1996, Magoulick and Wilzbach 1998, Schroeter 1998, Novinger 2000, Buys 2002). Lastly, competition between cutthroat trout and brook trout is probably intensified because they have similar food and habitat requirements (Griffith 1974, Hilderbrand 1998, Kruse 1999, Dunham et al. 2000, Hilderbrand and Kershner 2004).

To test for competition, workers have performed a variety of experiments to get cutthroat

${ }^{1}$ Watershed Science Department and Ecology Center, Utah State University, Logan, UT 84322-5210.

2 Appalachian Laboratory, University of Maryland Center for Environmental Science, Frostburg, MD 21532.

${ }^{3}$ Fish and Aquatic Ecology Unit, USDA Forest Service, Watershed Science Department, Utah State University, Logan, UT 84322-5210.

${ }^{4}$ Present address: Blasland, Bouck \& Lee, Inc., 6723 Towpath Road, Syracuse, NY 13214.

${ }^{5}$ Corresponding author. Present address: Northern Rocky Mountain Science Center, U.S. Geological Survey, 211 AJM Johnson Hall, Montana State University, Bozeman, MT 59717-3492. E-mail: jkershner@usgs.gov 


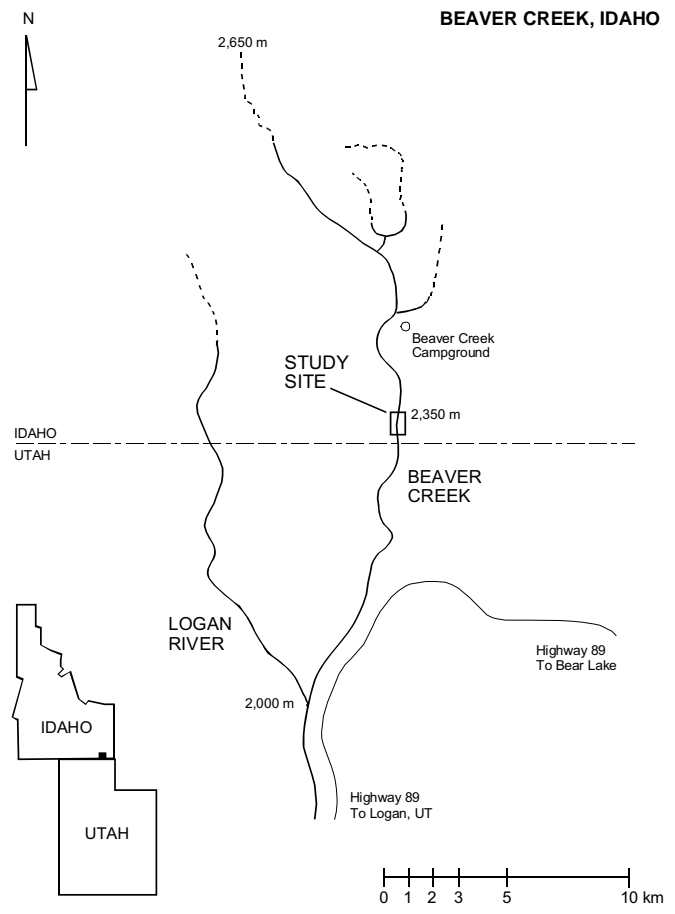

Fig. 1. Study site located on Beaver Creek, Idaho.

trout and brook trout to interact. Most experiments have occurred in laboratory stream channels (Griffith 1972, DeStaso and Rahel 1994, Thomas 1996, Novinger 2000, Buys 2002) or in fenced stream enclosures (Thomas 1996, Hilderbrand 1998, Schroeter 1998, Novinger 2000). Other less rigorous studies have been conducted using stream surveys (Griffith 1972, Nakano et al. 1998). Different response variables have been measured in these studies to directly or indirectly document competition. Direct measures of competition have included the observation of agonistic behavior or feeding interference, whereas indirect measures have included growth, microhabitat use, or emigration in other species (Connell 1983).

Among the many published competition studies, few examine the effects of fish density on competition between cutthroat trout and brook trout. Schroeter (1998) found that when brook trout occur at high densities, cutthroat trout feeding rate and territory occupancy are significantly reduced. He suggested that fish density might be a factor that facilitates the observed patterns of segregation between cutthroat trout and brook trout coexisting in the same stream. Peterson et al. (2004) speculated that the presence of brook trout in high densities may reduce age- 0 recruitment and subsequent survival for cutthroat trout and that this interaction at the youngest life stages may be a critical mechanism for replacement.

Our objective was to determine the effects of fish density on potential interactions between Bonneville cutthroat trout O. c. utah and brook trout. We hypothesize that fish density may play an important role in determining the growth, distribution, and displacement of native cutthroat trout when in the presence of introduced brook trout. We predict that negative interactions will be most pronounced at higher fish densities where stream resources are limited. At high densities, dominant fish will likely outcompete and exclude subdominant fish from even marginal habitats. Exclusion of subdominant fish may result in detrimental effects to their physical health and condition (Elliott 1990).

\section{METHODS}

\section{Study Area}

Beaver Creek is a second-order stream in the Bear River drainage that originates at 2400 $\mathrm{m}$ elevation. It flows south from Idaho for approximately $10 \mathrm{~km}$ before crossing into Utah and continues another $9 \mathrm{~km}$ before entering the Logan River. Approximately $60 \mathrm{~km}$ of connected stream are available to fish. Beaver Creek contains self-sustaining populations of stream-resident Bonneville cutthroat trout and brook trout. Densities are relatively high, averaging more than 0.1 trout $\cdot \mathrm{m}^{-2}$. The study location resides in the uppermost $6 \mathrm{~km}$ of stream occupied by trout (Fig. 1). This area is entirely national forest with minor recreational and cattle-grazing impacts. Habitat conditions include high-gradient reaches $(3 \%)$ with step pools under a forest canopy of lodgepole pine Pinus contorta and Douglas-fir Pseudotsuga menziesii, low gradient reaches $(1 \%-2 \%)$ that meander through grassy meadows, and beaver ponds with dams constructed primarily of willow Salix spp. Our study sections were located in the low-gradient reaches, where both species are sympatric.

\section{Experimental Methods}

In 1997, we placed equal numbers of wild Bonneville cutthroat trout and wild brook trout into fenced stream enclosures in Beaver Creek, Idaho (Fig. 1), to test for potential competitive 
effects. Beaver Creek is a high-elevation, second-order mountain stream with naturally reproducing sympatric populations of both trout species (Hilderbrand 1998). We measured fish growth and emigration rates as the response variables during 2 enclosure trials (1997-A and 1997-B) to indirectly document competition. We used 3 density treatments relative to the ambient conditions occurring naturally in the creek in order to ensure a competitive response and to determine density-related effects. Ambient densities were defined in previous studies by Hilderbrand (1998) and Buys (2002). The 3 density treatments were low $\left(0-0.07\right.$ fish $\left.\cdot \mathrm{m}^{-2}\right)$, ambient $\left(0.08-0.25\right.$ fish $\left.\cdot \mathrm{m}^{-2}\right)$, and high $\left(0.3-0.45\right.$ fish $\left.\cdot \mathrm{m}^{-2}\right)$. We also assessed the influence of intraspecific competition (cutthroat trout only) under ambient densities.

1997-A EXPERIMENT.-During the month of August 1997, we conducted concurrent experiments to test the effects of competition on fish growth and emigration. We established 5 replicates each of the ambient-density and lowdensity trials to document interspecific competition. The ambient density $(0.08-0.25$ fish $\mathrm{m}^{-2}$ ) treatment consisted of similarly sized and equally numbered (up to 4 each) tagged cutthroat trout $\left(21.1 \mathrm{~cm}, s_{\bar{x}}=0.6\right)$ and tagged brook trout $\left(20.4 \mathrm{~cm}, s_{\bar{x}}=0.7\right)$ stocked into five 12-meter-long stream enclosures for 31 days. Fish growth and emigration were the response variables measured. Whereas growth was measured at the end of each trial, emigration was measured daily using one-way fish traps built into the upstream and downstream fences of the ambient-density enclosures only. All fish attempting to emigrate during a trial were placed back into the stream enclosure from which they came. In order to meet the low-density requirement $\left(0-0.07 \mathrm{fish} \cdot \mathrm{m}^{-2}\right)$, we stocked equal numbers (up to 4 each) of similarly sized tagged cutthroat trout $(21.6 \mathrm{~cm}$, $\left.s_{\bar{x}}=0.5\right)$ and tagged brook trout $\left(19.8 \mathrm{~cm}, s_{\bar{x}}\right.$ $=0.4$ ) into five 30 -meter-long stream enclosures for 31 days. Fish growth was the response variable measured at the end of the trial.

We stocked similar numbers (up to 8 fish total) of cutthroat trout only $\left(20.5 \mathrm{~cm}, s_{\bar{x}}=\right.$ 0.3 into another set of five 12-meter-long stream enclosures to form an allopatric treatment to evaluate the effects of intraspecific competition on growth at ambient densities. Fish growth and emigration were the response variables measured. Intraspecific tests with allopatric cutthroat trout at low fish densities were not conducted.

Concurrent with the enclosure experiments, ambient densities of similarly sized tagged cutthroat trout $\left(n=33, \bar{x}=19.3 \mathrm{~cm}, s_{\bar{x}}=0.4\right)$ and tagged brook trout $n=28, \bar{x}=18.4 \mathrm{~cm}$, $\left.s_{\bar{x}}=0.5\right)$ were stocked into a $200-\mathrm{m}$ unrestricted reach of Beaver Creek. We termed fish in this 200-m section as "free-range" and tested for cage effects during the 1997-A experiment by comparing the growth of freerange fish to the growth of fish in the ambient-density stream enclosures. Lack of differences in fish growth between the free-range fish and ambient density stream-enclosure fish would likely indicate that enclosure results were from competition rather than from cage effects.

Stream conditions in the enclosures and in the unrestricted 200-m reach of Beaver Creek during the 1997-A experiment were as follows: mean channel width of $3.9 \mathrm{~m}\left(s_{\bar{x}}=0.1\right.$, range $2.5-5.5 \mathrm{~m})$, mean channel depth of $0.27 \mathrm{~m}\left(s_{\bar{x}}\right.$ $=0.02$, maximum $=0.80 \mathrm{~m}$ ), mean stream flow of $0.21 \mathrm{~m} \cdot \mathrm{s}^{-1}\left(s_{\bar{x}}=0.01\right)$, and mean water temperature of $7.8^{\circ} \mathrm{C}\left(s_{\bar{x}}=0.1\right.$; range $\left.3.0-12.8^{\circ} \mathrm{C}\right)$.

1997-B EXPERIMENT.-During the month of September 1997, we randomly selected fish used during the 1997-A study to use in conducting the 1997-B study. We restocked at high densities $\left(0.3-0.45\right.$ fish $\left.\cdot \mathrm{m}^{-2}\right)$ equal numbers (up to 8 each) of similarly sized tagged cutthroat trout $\left(21.5 \mathrm{~cm}, s_{\bar{x}}=0.4\right)$ and tagged brook trout $\left(21.2 \mathrm{~cm}, s_{\bar{x}}=0.3\right)$ into five 12 -meter stream enclosures for 29 days to evaluate the effects of interspecific competition at this density. We measured fish growth and emigration as the response variables. Comparable intraspecific tests using only cutthroat trout were not conducted at this density because the tests would have required an unacceptably large number of cutthroat trout for replication.

We tested for time effects during the 1997B experiment by restocking tagged cutthroat trout $\left(n=22, \bar{x}=20.1 \mathrm{~cm}, s_{\bar{x}}=0.5\right)$ and tagged brook trout $\left(n=23,19.9 \mathrm{~cm}, s_{\bar{x}}=0.5\right)$ at ambient densities $\left(0.08-0.25\right.$ fish $\left.\cdot \mathrm{m}^{-2}\right)$ back into the unrestricted $200-\mathrm{m}$ reach and compared their growth to the growth of the ambient-density, free-range fish that occupied this section during the 1997-A study. Differences in fish growth between the 1997-A and 1997-B ambient-density, free-range fish may indicate the presence of time effects. The presence of 
time effects would likely preclude the use of statistical tests between the 2 studies (1997-A and 1997-B). However, the presence of a freerange, ambient-density reference during both experiments allows for inference about the relative effects of density in the face of time effects.

Stream conditions in the enclosures and in the unrestricted 200-m reach of Beaver Creek during the 1997-B experiment were as follows: mean stream flow of $0.19 \mathrm{~m} \cdot \mathrm{s}^{-1}\left(s_{\bar{x}}=0.01\right)$ and mean water temperature of $5.6{ }^{\circ} \mathrm{C}\left(s_{\bar{x}}=\right.$ 0.1 ; range $\left.0.8-11.1{ }^{\circ} \mathrm{C}\right)$. Channel width and depth were reported previously in the 1997-A section.

\section{Statistical Methods}

We used analysis of variance (ANOVA) to test for among-group differences in fish growth and emigration rates across trials, including cage-effect tests, and to test for time effects between individuals in the 1997-A and 1997-B experiments. We used the Spearman rank correlation to examine the relationship between response variables. An $\alpha$ level of 0.05 was used to evaluate statistical significance. All statistical tests were performed on natural-log-transformed data to better meet assumptions of normality and homogeneity of variance. In addition, we standardized fish growth to account for differences in fish size $\left(\log _{e} g \cdot \mathrm{g}^{-1} \mathrm{~d}^{-1} \cdot 10^{4}\right)$. It was not necessary to standardize the emigration data $\left(\log _{e}\right.$ movements $\cdot$ fish $^{-1}$ study $\left.^{-1}\right)$.

\section{RESUlTS}

\section{Time Effects}

Strong time effects were present between the 1997-A and 1997-B 200-m free-range experiments. Both cutthroat trout and brook trout gained weight in the 1997-A and 1997-B ambient-density, free-range experiments; however, weight gain in 1997-A was significantly higher than in $1997-\mathrm{B}\left(F_{1,44}=9.30, P=0.004\right)$. Total weight gain in grams by cutthroat trout and brook trout was $8.2\left(s_{\bar{x}}=1.2\right)$ and $9.3\left(s_{\bar{x}}=1.5\right)$ in 1997-A and $6.3\left(s_{\bar{x}}=1.9\right)$ and $3.9\left(s_{\bar{x}}=0.9\right)$ in 1997-B, respectively (Table 1 ). Weight gain was higher in 1997-A, even though approximately $36 \%$ more fish were stocked into the 200-m reach during this experiment (Table 1). We found no differences between species $\left(F_{1,44}\right.$ $=0.08, P=0.775)$, nor was there a time $\times$ species interaction $\left(F_{1,44}=1.02, P=0.318\right)$. 


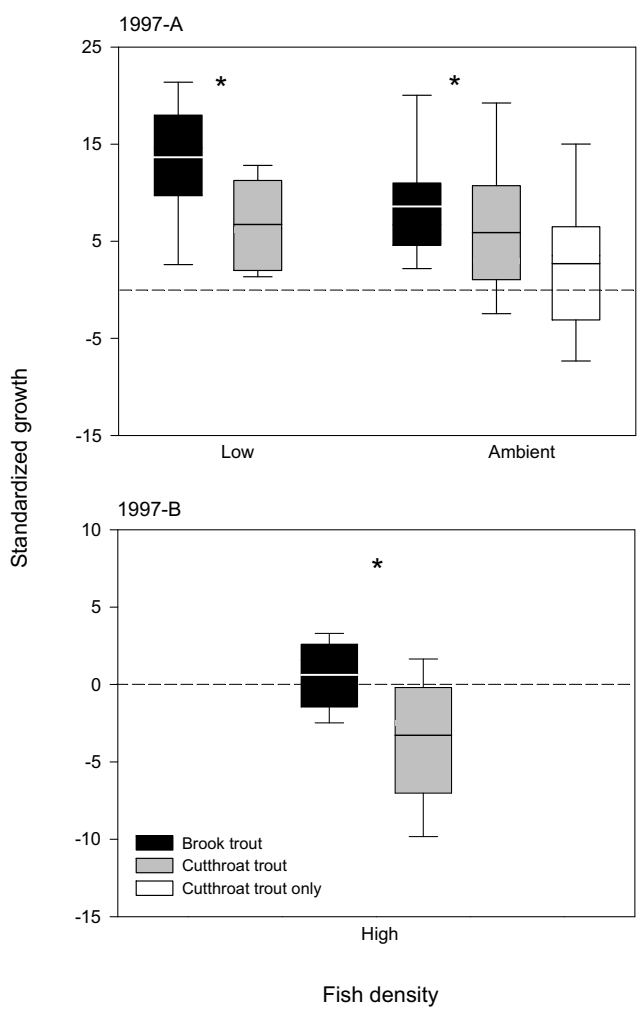

Fig. 2. Relationships between fish density and growth (g) across trials of sympatric brook trout and cutthroat trout and for allopatric cutthroat trout. Represented are the mean, the 25th and 75th percentiles (box ends), and the 5th and 95th percentiles (whisker bars). An asterisk (*) denotes statistical significance $(P<0.05)$.

The implication of this finding was that it was inappropriate to conduct statistical tests between the different experiments because of the confounding factors of time. We therefore confined our statistical analyses to within individual experiments only.

\section{Cage Effects}

We found no evidence for cage effects on growth during our experiments; growth rates were similar between the 1997-A ambientdensity, stream-enclosure fish and the 1997-A ambient-density, free-range fish (Table $1 ; F_{1,44}$ $=0.23, P=0.656$ ).

\section{Growth}

Brook trout always outgrew cutthroat trout within a trial, and the differences were more pronounced as fish density increased. In the highest density trial, cutthroat trout lost weight
(Fig. 2). Total weight gain by cutthroat trout and brook trout was $11.9 \mathrm{~g}\left(s_{\bar{x}}=1.9\right)$ and $22.7 \mathrm{~g}$ $\left(s_{\bar{x}}=3.3\right)$ at low densities $\left(F_{1,4}=20.8, P=\right.$ $0.010) ; 6.8 \mathrm{~g}\left(s_{\bar{x}}=1.9\right)$ and $12.1 \mathrm{~g}\left(s_{\bar{x}}=2.4\right)$ at ambient densities $\left(F_{1,4}=11.1, P=0.029\right)$; and $-3.6 \mathrm{~g}\left(s_{\bar{x}}=1.0\right)$ and $1.1 \mathrm{~g}\left(s_{\bar{x}}=0.4\right)$ at high densities $\left(F_{1,4}=17.5, P=0.014\right)$, respectively (Table 1). We found no differences in weight gains of cutthroat trout at ambient densities between inter- or intraspecific trials $\left(F_{1,8}=0.79, P=0.401\right.$; Fig. 2$)$.

\section{Emigration}

Emigration by cutthroat trout substantially increased as fish density increased, but brook trout remained largely unaffected. In the ambient-density, stream-enclosure experiment (Fig. 3 ), cutthroat trout had higher emigration rates, but the difference was not significant $\left(F_{1,4}=\right.$ 1.44, $P=0.296)$. The number of emigration attempts displayed by ambient-density cutthroat trout and brook trout was $0.69\left(s_{\bar{x}}=\right.$ $0.18)$ and $0.50\left(s_{\bar{x}}=0.18\right)$ moves $\cdot$ fish $^{-1}$ study $^{-1}$, respectively (Table 2). However, emigration by cutthroat trout in the high-density, streamenclosure experiment was significantly higher (1.7 times greater) than emigration by brook trout (Fig. $3 ; F_{1,4}=29.8, P=0.006$ ) at 1.13 $\left(s_{\bar{x}}=0.16\right)$ and $0.65\left(s_{\bar{x}}=0.16\right)$ moves $\cdot$ fish $^{-1}$ study $^{-1}$, respectively (Table 2 ). No difference in cutthroat trout emigration existed at ambient densities for inter- or intraspecific trials (Fig. 3; $\left.F_{1,8}=0.03, P=0.866\right)$ at $0.69\left(s_{\bar{x}}=\right.$ $0.18)$ and $0.71\left(s_{\bar{x}}=0.16\right)$ moves $\cdot$ fish $^{-1}$ study $^{-1}$, respectively (Table 2 ).

The results of our emigration study reflect the movement of many fish, rather than the movement of a few fish that had the tendency to move (Table 2). In total, $47 \%$ of the ambient-density interspecific fish and $50 \%$ of the ambient-density intraspecific fish attempted to emigrate. In the high-density test, approximately $58 \%$ of the fish attempted to emigrate. The majority of these fish emigrated only once or twice during an experiment, with the maximum number of emigration attempts being 4 times (Fig. 4). In the ambient-density tests, most emigration attempts were in the upstream direction, with upstream movement occurring at a rate of $75 \%$ for brook trout, $36 \%$ for cutthroat trout, and $65 \%$ for intraspecific cutthroat trout. In the high-density tests, upstream movement occurred at a rate of $85 \%$ for brook trout and $71 \%$ for cutthroat trout. 


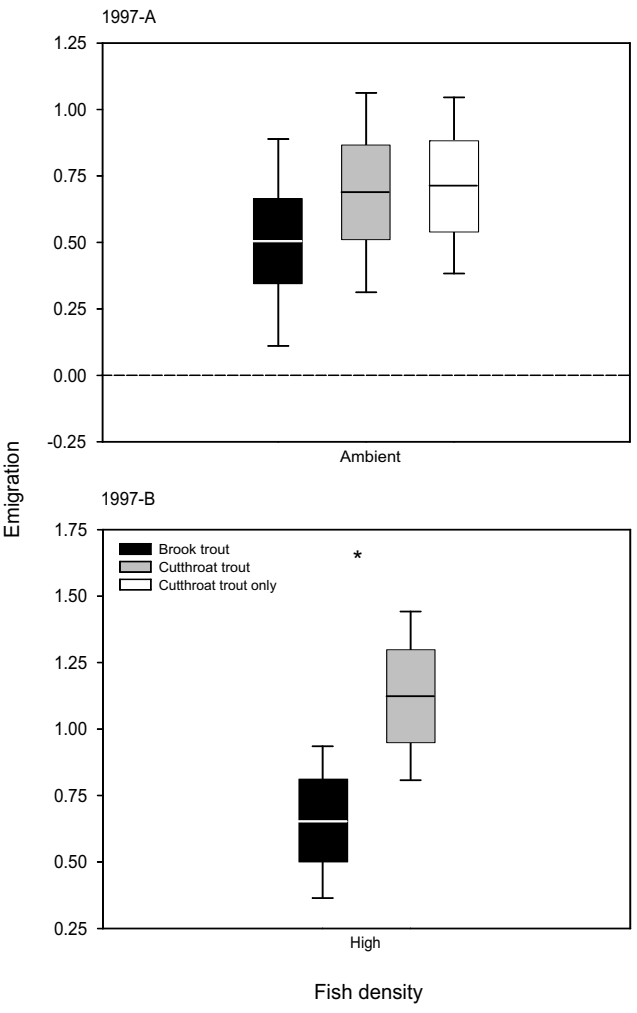

Fig. 3. Relationships between fish density and emigration (moves · fish $^{-1}$ study $^{-1}$ ) across trials of sympatric brook trout and cutthroat trout and for allopatric cutthroat trout. Represented are the mean, one standard error (box ends), and the 5th and 95th percentiles (whisker bars). An asterisk $\left(^{*}\right)$ denotes statistical significance $(P<0.05)$.

\section{Correlation between Growth and Emigration}

We observed a strong negative correlation between fish growth and emigration for cutthroat trout in interspecific trials at both the ambient-density $\left(r_{\mathrm{s}}=-0.63, n=11, P=\right.$ $0.032)$ and the high-density $\left(r_{\mathrm{s}}=-0.68, n=\right.$ $14, P=0.007)$ stream-enclosure experiments (Fig. 4). We observed no indication that these variables were correlated for brook trout at either ambient $\left(r_{\mathrm{s}}=-0.19, n=9, P=0.612\right)$ or high densities $\left(r_{\mathrm{s}}=-0.04, n=13, P=\right.$ 0.892 ), or for cutthroat trout in intraspecific trials at ambient densities $\left(r_{\mathrm{s}}=-0.18, n=13\right.$, $P=0.553 ;$ Fig. 4).

\section{DisCusSION}

Our results indicate that brook trout gain more weight and emigrate less than cutthroat trout when the species are placed together in 


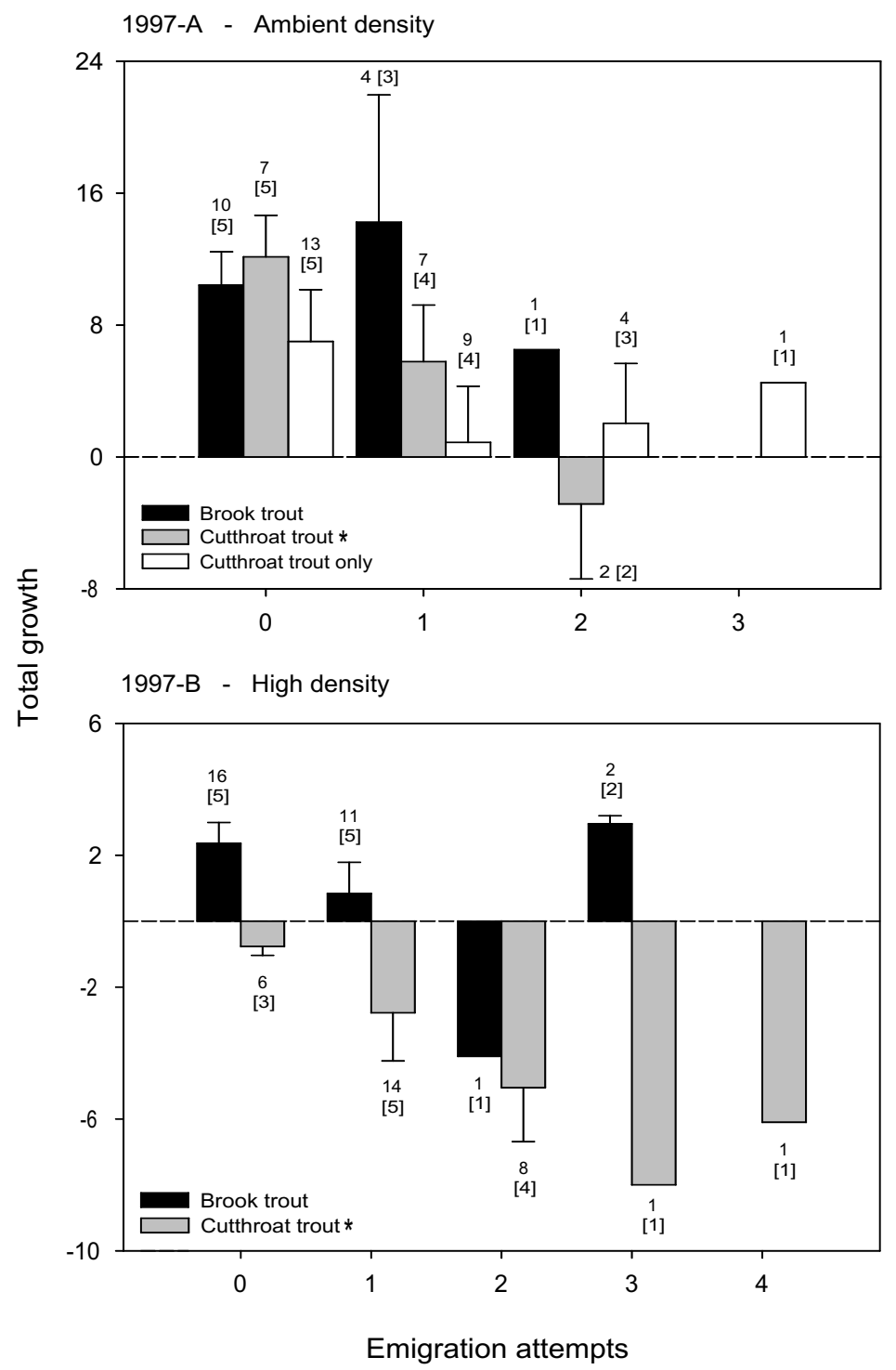

Fig. 4. Relationships between mean fish growth $(\mathrm{g})$ and emigration attempts across trials of sympatric brook trout and cutthroat trout and for allopatric cutthroat trout. Values by each bar reflect the number of fish [and replicates] in that group. An asterisk $(*)$ in the legend indicates a significant relationship $(P<0.05)$ for that species. Whisker bars represent one standard error.

fenced stream enclosures, and these effects are particularly apparent at higher densities. Brook trout also appear capable of maintaining positive growth under increasing fish densities, while cutthroat trout growth is dramatically reduced. Our results suggest that higher densities of both brook trout and cutthroat trout cause a decline in growth and increased emigration in cutthroat trout. Brook trout may have the ability to exclude cutthroat trout from preferred feeding areas (our stream enclosures were placed in a very productive stretch of Beaver Creek known to contain many cutthroat trout), and as a result, cutthroat trout may lose weight and try to emigrate more frequently in search of other available habitats.

Brook trout reduced juvenile cutthroat trout survival at mid-elevation habitats in Colorado (Peterson et al. 2004). Thomas (1996) observed brook trout capturing more food items than 
cutthroat trout in the laboratory; and in the field, cutthroat trout had reduced lipid levels when brook trout were present. DeStaso and Rahel (1994) reported brook trout being more aggressive and outcompeting cutthroat trout for food and habitat resources at higher water temperatures. Novinger (2000) and Schroeter (1998) observed similar findings: brook trout were more aggressive, captured more food items, and either gained more weight or had greater feeding efficiency than cutthroat trout.

Resources appear to be limiting to cutthroat trout regardless of the presence of brook trout. Cutthroat trout that did best in the allopatric tests grew much less than those individuals that did best (primarily brook trout) in the sympatric tests. This finding supports the hypothesis that competition for essential resources may be greatest within a species due to the absence of niche partitioning (Underwood 1986). This finding is also consistent with other cutthroat trout and brook trout studies that show greater effects from intraspecific competition (Nilsson and Northcote 1981, Kennedy and Strange 1986, Kocik and Taylor 1994, Byorth and Magee 1998, Schroeter 1998, Buys 2002).

The effects of fish density on competition in our experiments are more speculative due to the presence of time effects. In our study, time effects were likely caused by cooling water temperatures between experiments. As such, time effects could not be distinguished from possible density-related effects. Statistical tests were therefore limited to within experiments only, and any comparisons made between the different density treatments were necessarily subjective. Because of this, we approached the comparative analysis of fish density with caution.

In all 3 densities, we observed brook trout gaining more weight than cutthroat trout and cutthroat trout actually losing weight at the highest density. Similar incremental declines occurred in growth of coho salmon as steelhead trout densities increased by 1 and 2 times (Harvey and Nakamoto 1996). However, decreased growth was not restricted to cutthroat trout; we observed decreasing growth in both species as fish density increased. This negative relationship has been widely reported for both species in aquaculture (Vijayan et al. 1990, Kindschi and Koby 1994, Wagner et al. 1997, Marchand and Boisclair 1998).

Cutthroat trout attempted to emigrate more than brook trout at high densities. Greater emigration by cutthroat trout may be due to the presence of competing brook trout or due to less tolerance for higher densities of individual fish, regardless of species. Schroeter (1998) observed brook trout excluding cutthroat trout from preferred feeding areas at high densities, while Marchand and Boisclair (1998) observed brook trout displaying significantly more competitive interactions when densities were high. Peterson and Fausch (2003) reported invading brook trout placing pressure on the downstream limit of a cutthroat trout population, as nearly $80 \%$ of captured, marked brook trout moved upstream.

Although cutthroat trout and brook trout responded similarly to increasing fish density, the effects on brook trout appeared to be less dramatic. Given the relative growth differences between both species, brook trout appear to be able to mediate the effects of crowding by utilizing limited stream resources. Brook trout are known to occur at high densities in the wild (Griffith 1972, Johnson et al. 1992, Dunham et al. 2000) and may be able to withstand higher densities than cutthroat trout can tolerate (Schroeter 1998). The ability of brook trout to persist at high densities is best reflected in their tendency to school in large groups (Power 1980) and to occupy beaver ponds in dense congregations (Johnson et al. 1992).

Compared to cutthroat trout, brook trout may also have a more efficient feeding strategy, greater plasticity in feeding, and the ability to switch feeding modes based on the availability of invertebrate drift or benthos (McLaughlin 2001). Brook trout select bigger, more-energetically profitable food items than cutthroat trout (Dunham et al. 2000). This behavior may promote greater growth as well as facilitate a size-dominance hierarchy that could result in the displacement of cutthroat trout (Griffith 1972, Novinger 2000, Buys 2002). It is unlikely, however, that the findings from our study are due solely to the ability of brook trout to outgrow cutthroat trout, since cutthroat trout and brook trout in Beaver Creek have similar growth rates and feeding preferences (Hilderbrand 1998).

Brook trout appear to have an advantage over cutthroat trout in acquiring limited food and habitat resources. Although our experiment was not designed to identify specific mechanisms, we documented brook trout outgrowing cutthroat trout in all 3 density treatments, with 
the most significant differences occurring at high densities where cutthroat trout lost weight. Weight loss by cutthroat trout during the summer growing season may cause many cutthroat trout to have fewer reserves for winter and to experience a higher rate of mortality (Thomas 1996).

In contrast with other studies that have documented the decline and ultimate displacement of cutthroat trout, we observed interactions between 2 species that have existed together since the early 1900s. While we are unsure of the current trajectory of the invasion, there appears to be coexistence in almost all areas of Beaver Creek. There may be a number of explanations for this. Brook trout are absent in highgradient reaches, a situation which may provide important refugia for Bonneville cutthroat (Hilderbrand 1998). Bonneville cutthroat in Beaver Creek are also connected to a larger fluvial system in the Logan River and exist in a well-connected system of tributaries. Larger fluvial fish are still present in the Logan River, and the ability of cutthroat to freely migrate may provide additional population support. Brook trout are typically found at much lower densities in the upper Logan River (unpublished data) once Beaver Creek joins the river.

In addition, brown trout are present in the lower Logan River and in small mainstem reservoirs. Brown trout have occupied the river for over 100 years (Budy et al. 2003). While negative effects of brown trout on Bonneville cutthroat have been documented, Bonneville cutthroat are still well distributed in the main stem and in other tributaries of the river above an irrigation reservoir that blocks upstream migration. McHugh and Budy (2005) speculate that temperature conditions in the upstream areas of Logan River may limit colonization by brown trout, thereby limiting the zone of interaction.

Bonneville cutthroat trout in the Logan River represent a unique native-trout fishery that has persisted for a relatively long period of time in the presence of 2 nonnative competitors. While introductions of nonnative trout have contributed to the decline and eventual disappearance of native cutthroat trout elsewhere, Bonneville cutthroat trout have managed to persist in this system. Although we are unsure of the current trajectory of the invasion, we believe that there is a unique opportunity to continue investigations into the interactions between these species and to explore the mechanisms responsible for their coexistence.

\section{ACKNOWLEDGMENTS}

Thanks go to Susan Durham for her assistance with statistical analysis and to Drs. Jim McMahon and Todd Crowl for their helpful reviews on previous versions of this manuscript. Thanks also go to biologist Hans Berge who contributed greatly to this work through his advice and field assistance. Funding was graciously provided by the National Fish and Wildlife Foundation's "Bring Back the Natives" program and also by the USDA Forest Service Fish and Aquatic Ecology Unit.

\section{Literature Cited}

BEHnKe, R.J. 1992. Native trout of western North America. Monograph 6, American Fisheries Society, Bethesda, MD.

BEHNKe, R.J., AND M. Zarn. 1976. Biology and management of threatened and endangered western trouts. General Technical Report RM-28, USDA Forest Service, Fort Collins, CO.

Budy, P.B., E. de la Hoz Franco, G.P. Thiede, and S. VATLAND. 2003. Logan River whirling disease study: factors affecting trout population dynamics, abundance, and distribution in the Logan River, Utah. Annual Report to the Utah Division of Wildlife Resources, Utah Cooperative Fish and Wildlife Research Unit, Logan.

Burs, D.J. 2002. Competition between Bonneville cutthroat trout and brook trout in laboratory and field experiments. Master's thesis, Utah State University, Logan.

Byorth, P.A., AND J.P. MageE. 1998. Competitive interactions between arctic grayling and brook trout in the Big Hole River drainage, Montana. Transactions of the American Fisheries Society 127:921-931.

ConnelL, J.H. 1983. On the prevalence and relative importance of interspecific competition: evidence from field experiments. American Naturalist 122: $661-696$.

DeStaso, J., III, AND F.J. RaheL. 1994. Influence of water temperature on interactions between juvenile Colorado River cutthroat trout and brook trout in a laboratory stream. Transactions of the American Fisheries Society 123:289-297.

Dunham, J.B., S.B. Adams, R.E. Schroeter, and D.C. Novinger. 2002. Alien invasions in aquatic ecosystems: toward an understanding of brook trout invasions and potential impacts on inland cutthroat in western North America. Reviews in Fish Biology and Fisheries 12:373-391.

Dunham, J.B., M.E. Rahn, R.E. Schroeter, and S.W. BRECK. 2000. Diets of sympatric Lahontan cutthroat trout and nonnative brook trout: implications for species interactions. Western North American Naturalist 60:304-310.

ELLIOTT, J.M. 1990. Mechanisms responsible for population regulation in young migratory trout, Salmo trutta: 
the role of territorial behavior. Journal of Animal Ecology 59:803-818.

Eiserman, F. 1958. A fisheries survey of the Little Snake River drainage. Wyoming Game and Fish Commission, Fisheries Technical Report 6, Cheyenne.

Gibson, R.J., D.E. Stansbury, R.R. Whalen, and K.G. HiLLIER. 1993. Relative habitat use, and interspecific and intraspecific competition of brook trout, Salvelinus fontinalis, and juvenile Atlantic salmon, Salmo salar, in some Newfoundland rivers. Canadian Special Publication of Fisheries and Aquatic Sciences 118:53-69.

GRESSWELL, R.E. 1991. Use of antimycin for removal of brook trout from a tributary of Yellowstone Lake. North American Journal of Fisheries Management 11:83-90.

Griffith, J.S. 1972. Comparative behavior and habitat utilization of brook trout, Salvelinus fontinalis, and cutthroat trout, Salmo clarki, in small streams in northern Idaho. Journal of Fisheries Research Board of Canada 29:265-273

1974. Utilization of invertebrate drift by brook trout, Salvelinus fontinalis, and cutthroat trout, Salmo clarki, in small streams in Idaho. Transactions of the American Fisheries Society 103:440-447.

Harvey, B.C., and R.J. NaKamoto. 1996. Effects of steelhead density on growth of coho salmon in a small coastal California stream. Transactions of the American Fisheries Society 125:237-243.

Hilderbrand, R.H. 1998. Movements and conservation of cutthroat trout. Doctoral dissertation, Utah State University, Logan.

Hilderbrand, R.H., and J.L. Kershner. 2004. Influence of habitat type on food supply, selectivity, and diet overlap of Bonneville cutthroat trout and nonnative brook trout in Beaver Creek, Idaho. North American Journal of Fisheries Management 24: $33-40$.

Johnson, S.L., FJ. Rahel, and W.A. Hubert. 1992. Factors influencing the size structure of brook trout populations in beaver ponds in Wyoming. North American Journal of Fisheries Management 12 : 118-124.

Kennedy, G.J.A., and C.D. Strange. 1986. The effects of intra- and inter-specific competition on the distribution of stocked juvenile Atlantic salmon, Salmo salar, in relation to depth and gradient in an upland trout, Salmo trutta, stream. Journal of Fish Biology 29: 199-214.

Kindschi, G.A., And R.F. Koby. 1994. Performance and oxygen consumption of Snake River cutthroat trout reared at four densities with supplemental oxygen. Progressive Fish-Culturist 56:13-18.

KoCIK, J.F., AND W.W. TAYLOR. 1994. Summer survival and growth of brown trout with and without steelhead under equal total salmonine densities in an artificial stream. Transactions of the American Fisheries Society 123:931-938.

KRusE, C.G. 1999. Influence of non-native trout and geomorphology on distributions of indigenous trout in the Yellowstone River drainage of Wyoming. Doctoral dissertation, University of Wyoming, Laramie.

Magoulick, D.D., and M.A. Wilzbach. 1998. Effect of temperature and macrohabitat on interspecific aggression, foraging success, and growth of brook trout and rainbow trout pairs in laboratory streams. Transactions of the American Fisheries Society 127:708-717.
Marchand, F., AND D. Boisclair. 1998. Influence of fish density on the energy allocation pattern of juvenile brook trout, Salvelinus fontinalis. Canadian Journal of Fisheries and Aquatic Sciences 55:796-805.

McHugh, P., AND P. Budy. 2005. An experimental evaluation of competitive and thermal effects on brown trout (Salmo trutta) and Bonneville cutthroat trout (Oncorynchus clarkia utah) performance along an altitudinal gradient. Canadian Journal of Fisheries and Aquatic Sciences 62:2784-2795.

McLaughlin, R.L. 2001. Behavioural diversification in brook charr: adaptive responses to local conditions. Journal of Animal Ecology 70:325-337.

NaKano, S., S. Kitano, K. Nakai, and K.D. Fausch. 1998. Competitive interactions for foraging microhabitat among introduced brook charr, Salvelinus fontinalis, and native bull charr, S. confluentus, and westslope cutthroat trout, Oncorhynchus clarki lewisi, in a Montana stream. Environmental Biology of Fishes $52: 345-355$

Nehring, R.B., And K.G. Thompson. 2001. Impact assessment of some physical and biological factors in the whirling disease epizootic among wild trout in Colorado. Colorado Division of Wildlife Special Report No. 76, Fort Collins, CO.

Nilsson, N.A., AND T.G. Northcote. 1981. Rainbow trout, Salmo gairdneri, and cutthroat trout, S. clarki, interactions in coastal British Columbia lakes. Canadian Journal of Fisheries and Aquatic Sciences 38: $1228-1246$

NovingER, D.C. 2000. Reversals in competitive ability: do cutthroat trout have a thermal refuge from competition with brook trout? Doctoral dissertation, University of Wyoming, Laramie.

Oberholtzer, M. 1990. Current status of Colorado River cutthroat trout in the Little Snake River enclave. Fish Division, Wyoming Game and Fish Department, Project 5090-28-8501, Cheyenne.

Peterson, D.P., and K.D. Fausch. 2003. Upstream movement by nonnative brook trout (Salvelinus fontinalis) promotes invasion of native cutthroat trout (Oncorhynchus clarki) habitat. Canadian Journal of Fisheries and Aquatic Sciences 60:1502-1516.

Peterson, D.P., K.D. Fausch, and G.C. White. 2004. Population ecology of an invasion: effects of brook trout on native cutthroat trout. Ecological Applications 14:754-772.

Power, G. 1980. The brook charr, Salvelinus fontinalis. Pages 141-203 in E.K. Balon, editor, Charrs: salmonid fishes of the genus Salvelinus. Dr. W. Junk Publisher.

Remmick, R., K. Nelson, G. Walker, and J. Henderson. 1993. Bonneville cutthroat trout interagency fiveyear management plan (1993-1997). Draft management plan, Wyoming Game and Fish Department, Cheyenne.

Schroeter, R.E. 1998. Segregation of stream dwelling Lahontan cutthroat trout and brook trout: patterns of occurrence and mechanisms for displacement. Master's thesis, University of Nevada, Reno. vii $+93 \mathrm{pp}$.

Thомаs, H.M. 1996. Competitive interactions between a native and exotic trout species in high mountain streams. Master's thesis, Utah State University, Logan.

Townsend, C.R., And T.A. Crowl. 1991. Fragmented population structure in a native New Zealand fish: an effect of introduced brown trout? Oikos 61:347-354.

UnderwOOD, T. 1986. The analysis of competition by field experiments. Pages 240-268 in J. Kikkawa and D.J. 
Anderson, editors, Community ecology: pattern and process. Blackwell Scientific Publications, Palo Alto, $\mathrm{CA}$

ViJaYAN, M.M., J.S. BaLLANTYNE, and J.F. LEATHERLand, 1990. High stocking density alters the energy metabolism of brook charr, Salvelinus fontinalis. Aquaculture 88(3-4):371-382.

Wagner, E.J., T. Jeppsen, R. Arndt, D.M. Routledge, AND Q. BRADWISCH. 1997. Effects of rearing density upon cutthroat trout hematology, hatchery performance, fin erosion, and general health and condition. Progressive Fish-Culturist 59:173-187.

Received 1 April 2008 Accepted 12 May 2009 